\title{
Regulation of water, salinity, and cold stress responses by salicylic acid
}

\author{
Kenji Miura $^{1}{ }^{*}$ and Yasuomi Tada ${ }^{2}$ \\ 1 Faculty of Life and Environmental Sciences, University of Tsukuba, Tsukuba, Japan \\ 2 Faculty of Agriculture, Kagawa University, Kagawa, Japan
}

\section{Edited by:}

Yuriko Osakabe, RIKEN Plant Science

Center, Japan

\section{Reviewed by:}

Guillaume Pilot, Virginia Tech, USA

Roy Navarre, United Stated

Department of Agriculture, USA

\section{${ }^{*}$ Correspondence:}

Kenji* Miura, Faculty of Life and

Environmental Sciences, University of

Tsukuba, 1-1-1 Tennodai, Tsukuba

305-8572, Japan

e-mail:kmiura@gene.tsukuba.ac.jp

Salicylic acid (SA) is a naturally occurring phenolic compound. SA plays an important role in the regulation of plant growth, development, ripening, and defense responses. The role of SA in the plant-pathogen relationship has been extensively investigated. In addition to defense responses, SA plays an important role in the response to abiotic stresses, including drought, low temperature, and salinity stresses. It has been suggested that SA has great agronomic potential to improve the stress tolerance of agriculturally important crops. However, the utility of SA is dependent on the concentration of the applied SA, the mode of application, and the state of the plants (e.g., developmental stage and acclimation). Generally, low concentrations of applied SA alleviate the sensitivity to abiotic stresses, and high concentrations of applied induce high levels of oxidative stress, leading to a decreased tolerance to abiotic stresses. In this article, the effects of SA on the water stress responses and regulation of stomatal closure are reviewed.

\section{Keywords: reactive oxygen species, drought tolerance, stomata, salicylic acid, feedback loop}

\section{INTRODUCTION}

Salicylic acid (SA) is involved in the regulation of pathogenesisrelated protein expression, leading to plant defense against biotrophic pathogens (Dempsey et al., 2011). It also plays an important role in the regulation of plant growth, development, ripening, flowering, and responses to abiotic stresses (Rivas-San Vicente and Plasencia, 2011; Hara et al., 2012). In general, low concentrations of SA may enhance the antioxidant capacity in plants, but high concentrations of SA may cause cell death or susceptibility to abiotic stresses (Hara et al., 2012). Currently, little information is available about the molecular mechanisms of $\mathrm{SA}$ in response to abiotic stresses. The word "salicylic" is derived from Salix, which is the Latin name for the willow tree (Salix alba). Salicin, the glucoside of salicylic alcohol, was first isolated in 1826 from willow bark, and a large amount of the substance was successfully isolated in 1828 . Salicin was then converted into a sugar and an aromatic compound that, upon oxidation, becomes SA. SA, a 2-hydroxybenzoic acid (Figure 1), has a colorless crystalline structure and is widely used in organic synthesis, including the synthesis of aspirin, also known as acetylsalicylic acid. Plants generally contain a few micrograms of SA or less per gram of fresh weight (Raskin, 1992), either in a free state or in a glycosylated, methylated, glucose-ester, or amino acid conjugate form (Figure 1; Dempsey et al., 2011).

\section{BIOSYNTHESIS AND SENSORY MECHANISMS OF SA}

$\mathrm{SA}$ is synthesized via two distinct pathways, the isochorismate (IC) pathway and the phenylalanine ammonia-lyase (PAL) pathway (Figure 1). These pathways begin with chorismic acid, which is the end product of the shikimate pathway and is synthesized in the plastid. The major pathway is the IC pathway in Arabidopsis thaliana, Nicotiana benthamiana, tomato, and other plants (Wildermuth et al., 2001; Uppalapati et al., 2007; Catinot et al., 2008). Chorismic acid is converted to IC by isochorismate synthase (ICS). ICS homologs have been identified in a wide variety of plant species, including tobacco, pepper, tomato, rice, grapevine, soybean, and poplar. ICS1/SID2 is an important gene in Arabidopsis because the mutant accumulates only $5-10 \%$ the level of SA compared with wild-type plants (Nawrath and Métraux, 1999; Dewdney et al., 2000). ICS1/SID2 is upregulated by not only biotic stresses but also abiotic stresses, including UV light (Kilian et al., 2007), ozone (Ogawa et al., 2005), and drought (Wan et al., 2012). An Arabidopsis ics1/sid2 ics2 double mutant exhibited an even lower, but not null, level of total SA (Garcion etal., 2008), suggesting the presence of an IC-independent pathway.

Although ICS is conserved in various plant species, the mechanism to convert IC to SA remains unclear. Isochorismate pyruvate lyase (IPL) may catalyze the conversion of IC to SA, given that some bacteria, such as Pseudomonas aeruginosa and Pseudomonas fluorescens, contain IPL (Serino et al., 1995; Mercado-Blanco et al., 2001). However, no plant gene encoding a protein with IPL activity has been identified. Another pathway is the PAL pathway (Figure 1). PAL, the first enzyme in this pathway, deaminates phenylalanine, leading to the production of trans-cinnamic acid. Trans-cinnamic acid is a precursor for the biosynthesis of diverse phenolic compounds, including lignin, lignans, flavonoids, volatile benzenoid esters, and benzoyl glucosinolates (Weng and Chapple, 2010; Dempsey et al., 2011). Thus, PAL plays an important role as a regulator between primary and secondary metabolism. Trans-cinnamic acid is converted to SA via two possible intermediates, ortho-coumaric acid and benzoic acid (BA; el-Basyouni etal., 1964; Ellis and Amrhein, 1971; Chadha and Brown, 1974; Yalpani et al., 1993). 


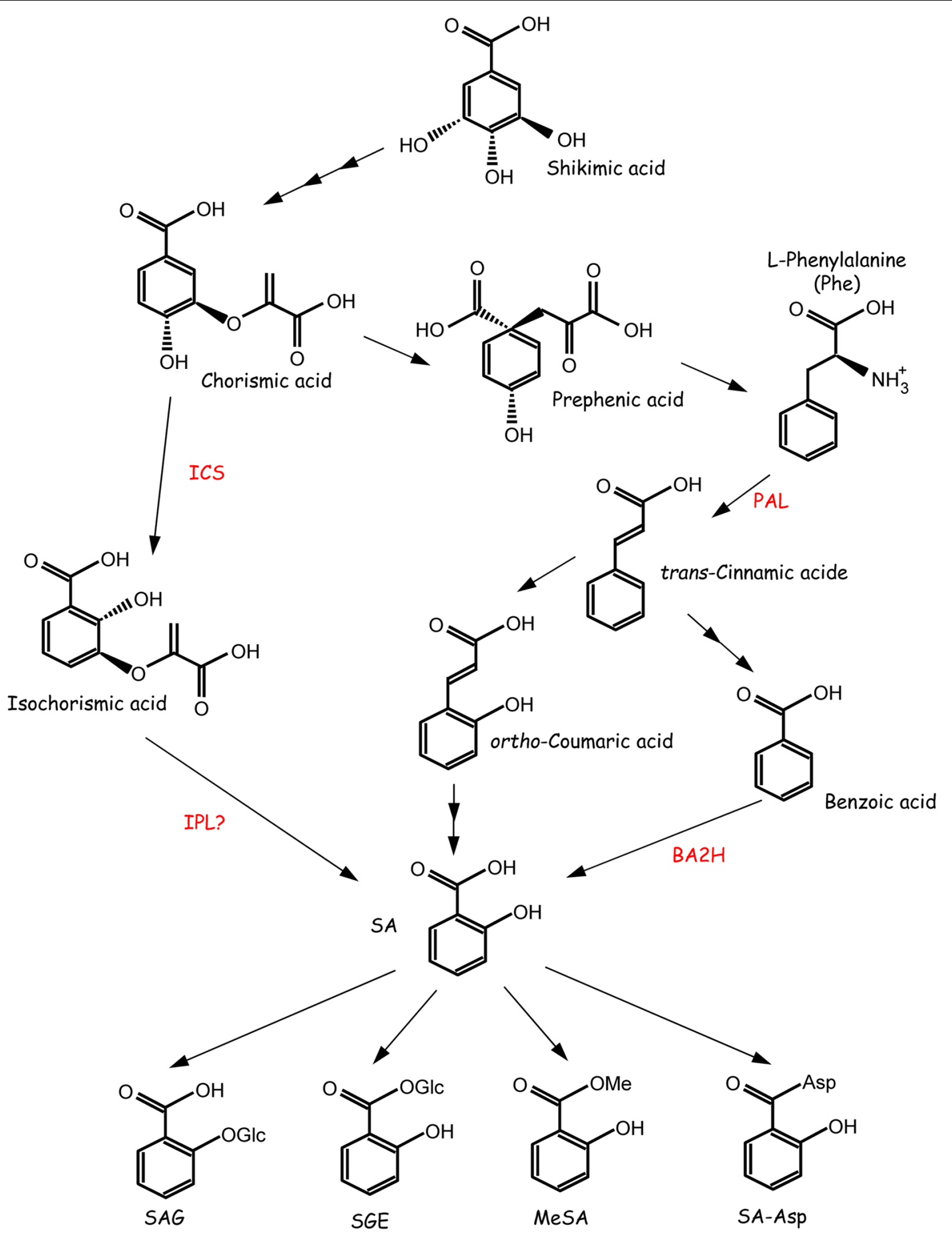

FIGURE 1 | Proposed pathways for SA biosynthesis and SA modification. SA is synthesized through the isochorismate (ICS) or phenylalanine ammonia-lyase (PAL) pathways. SA is also converted into several forms. BA2H, benzoic acid-2-hydroxylase; IPL, isochorismate pyruvate-lyase; MeSA, methyl salicylate; SA-Asp, salicyloyl-L-aspartic acid; SAG, salicylic acid 2-O- $\beta$-glucoside; SGE, salicyloyl glucose ester. The figure is adapted with permission from Dempsey etal. (2011). 
SA induces systemic acquired resistance (SAR), which includes global transcriptional reprogramming and immune responses to a broad spectrum of pathogens (Durrant and Dong, 2004). Previous studies identified some SA-binding proteins, such as catalase (Sanchez-Casas and Klessig, 1994), ascorbate peroxidase (APX; Du and Klessig, 1997), methyl SA esterase, and carbonic anhydrase (Slaymaker et al., 2002; Forouhar et al., 2005). These SA-binding proteins have been identified as important SA effector proteins, but genetic evidence suggests that they are not likely to function as bona fide SA receptors (Vlot et al., 2009). According to the large number of studies on SA-insensitive mutants, researchers thought that non-expressor of PR genes 1 (NPR1) could be an SA receptor candidate because nprl mutant plants exhibit a complete lack of resistance against biotrophic and hemibiotrophic pathogens (Delaney et al., 1995; Cao etal., 1997). Furthermore, the transcriptome analysis of wild-type and npr1 plants following treatment with BTH, a functional analog of SA, revealed that almost all BTH-responsive genes are under NPR1 control (Wang et al., 2006). NPR1 possesses a bric-a-brac/Pox virus, tramtrack, broad-complex (BTB) domain, an ankyrin repeat and a nuclear localization sequence, but it has no canonical DNA-binding domain (Cao et al., 1997). Although NPR1 has no canonical DNAbinding domain, NPR1 regulates almost all BTH-responsive genes, suggesting that NPR1 functions as a transcription co-activator in response to SA. However, the NPR1 protein does not show a biologically significant affinity for SA or its derivatives; therefore, another molecule needs to be identified as a receptor for SA.

Recently, the NPR1 paralogs NPR3 and NPR4 were identified as SA receptors that bind specifically to SA with different affinities (Fu et al., 2012). Both of the paralogs interact with the Cullin 3 (CUL3) ubiquitin E3 ligase to recruit NPR1 for proteasomemediated degradation in a SA concentration-dependent manner. As described above, NPR1 acts as a positive regulator of the SA-mediated defense signaling pathway. When the concentration of SA is low, an NPR4-NPR1 interaction is formed, and NPR4 constitutively promotes the degradation of NPR1 through CUL3mediated ubiquitylation. Thus, no immune response is activated. An increase in the SA concentration after pathogen attack leads to the binding of SA to NPR4. SA-NPR4 interferes with the NPR4NPR1 interaction. Because NPR1 is released from NPR4-mediated degradation, free NPR1 can now induce a hypersensitive response (HR), which is a form of programmed cell death that retards pathogenic growth. At very high concentrations, the SA levels are sufficient to bind to NPR3. SA-NPR3 promotes its interaction with NPR1. NPR3 is able to interact with CUL3, leading to ubiquitylation of NPR1. Thus, SA-NPR3-NPR1 formation enhances turnover of NPR1 mediated by proteasome (Fu et al., 2012).

\section{STOMATAL CLOSURE IS REGULATED BY SA, INDEPENDENT OF THE ABA PATHWAY}

The regulation of stomatal guard cells is an adaptive mechanism that helps plants withstand pathogenic infection and extreme environmental conditions, including drought. Stomata play an important role in the uptake of $\mathrm{CO}_{2}$ and transpiration. During water deficits, the stomata are closed to slow transpiration and conserve water in the plant, thereby decreasing the $\mathrm{CO}_{2}$ supply and leading to a reduction in photosynthesis. Stomatal opening or closure is achieved by the osmotic swelling or shrinking of guard cells, respectively (Liu and Luan, 1998). Plants control the width of the stomatal aperture in response to microorganism invasions (Blatt et al., 1999; Lee et al., 1999; Melotto et al., 2006) and various environmental signals (Hetherington and Woodward, 2003; Cominelli et al., 2005; Liang et al., 2005) as well as phytohormones. Unambiguously, abscisic acid (ABA) plays a substantial role in the regulation of stomatal closure under water stress (Aharoni et al., 1977; Tardieu and Davies, 1992; Schwartz et al., 1995; Leckie et al., 1998). Several studies have suggested that stomatal function is also regulated by auxin (Irving et al., 1992; Lohse and Hedrich, 1992; Gehring et al., 1998), cytokinin (Jewer and Incoll, 1980; Tanaka et al., 2006), ethylene (Desikan et al., 2006; Tanaka et al., 2006), brassinosteroids (Rajasekaran and Blake, 1999; Haubrick et al., 2006), jasmonate (Gehring et al., 1997; Suhita et al., 2004; Munemasa et al., 2007), and SA.

Because stomata are pores in the epidermis, pathogens can enter unchallenged. After an attack by a pathogen, the endogenous SA levels are increased to induce SAR. An increase in endogenous SA levels promotes stomatal closure. This closure is likely caused by the generation of reactive oxygen species (ROS), which is induced by SA (Melotto et al., 2006). The exogenous application of SA also induces ROS, $\mathrm{H}_{2} \mathrm{O}_{2}$, and $\mathrm{Ca}^{2+}$ accumulation, leading to stomatal closure (Dong et al., 2001; Liu et al., 2003; He et al., 2007). Two major mechanisms have been proposed for the generation of ROS during oxidative burst. One is mediated by plasma membrane $\mathrm{NAD}(\mathrm{P}) \mathrm{H}$ oxidases (Kwak et al., 2003), and another is mediated by cell wall peroxidases (Mori et al., 2001; Khokon et al., 2011). In addition to these enzymes, apoplast amine oxidases (Allan and Fluhr, 1997) and oxalate oxidases are able to generate ROS (Lane et al., 1993). Genetic and pharmacological studies suggest that ABA and methyl jasmonate stimulate $\mathrm{NAD}(\mathrm{P}) \mathrm{H}$ oxidase-mediated ROS production in guard cells (Munemasa et al., 2007; Saito et al., 2008). However, SA induces stomatal closure accompanied by extracellular ROS production that is mediated by salicylhydroxamic acid (SHAM)sensitive guaiacol peroxidases, intracellular ROS accumulation in guard cells, and $\mathrm{K}^{+}$in channel inactivation (Mori et al., 2001; Khokon et al., 2011).

After the contact of pathogenic bacteria with Arabidopsis leaves, stomatal closure is induced within $1 \mathrm{~h}$ (Melotto et al., 2006). Furthermore, the application of $0.4 \mathrm{mM}$ SA induces rapid stomatal closure within $2 \mathrm{~h}$ and a fourfold reduction of stomatal gas exchange in Arabidopsis (Melotto et al., 2006). This closure is compromised in the SA-deficient nahG and eds16-2 genotypes, suggesting that SA is required for stomatal defense (Melotto et al., 2006). The SA-accumulating mutants siz1 (Miura et al., 2005; Lee etal., 2007), acd6 (Rate et al., 1999), and cpr5 (Bowling et al., 1997) exhibit stomatal closure without any treatment (Miura et al., 2013). The stomatal closure of the siz1 mutant is compromised by the application of SHAM or azide, inhibitors of peroxidases, and not by diphenyliodonium (DPI) chloride, an inhibitor of $\mathrm{NAD}(\mathrm{P}) \mathrm{H}$ oxidase (Miura et al., 2013), suggesting that SA plays a role in the regulation of stomatal closure. Neither the ABA-insensitive mutant ost 1 nor the ABA-deficient mutant abi3-1 exhibit stomatal closure in response to flg22, a pathogenassociated molecular pattern (PAMP) elicitor or to the bacterial 
pathogen Pseudomonas syringae pv. tomato DC3000, respectively (Melotto et al., 2006). It is possible that positive cross-talk between $\mathrm{SA}$ and $\mathrm{ABA}$ is required to promote stomatal closure in response to pathogen invasion.

\section{EFFECTS OF SA ON DROUGHT RESPONSES}

Drought is the most common adverse environmental stress that seriously reduces crop productivity. The mechanism for drought avoidance is the maintenance of an adequate supply of water within the plant by growing long roots to reach deep soil moisture (Xiong et al., 2006) or the reduction of transpirational water loss to conserve water (Ackerson and Krieg, 1977). Thus, the stomata play a major role in plant adaptation to drought stress. Drought tolerance refers to the ability of a plant to withstand the loss of water content and regrow when moist conditions return. Resurrection plants have a mechanism to withstand approximately $90 \%$ water loss, whereas most other plants can withstand a moderate dehydration of approximately 30\% water loss. One characteristic symptom of water deficiency is the mobilization of the starch that is stored in the chloroplasts (Liu et al., 2004). During drought stress, the translocation of carbohydrates decreases, leading to a change in source-sink relationships (Liu et al., 2004). Water deficiency also causes a reduction of nutrient uptake due to the reductions in water migration and the quantity of ions transported by the water and to the retardation of root growth in dry soil (Rahman et al., 1971; Tanguilig et al., 1987). Plants have developed drought avoidance and/or dehydration tolerance to resist drought stresses.

In addition to $\mathrm{ABA}, \mathrm{SA}$ is involved in the regulation of drought responses. Endogenous SA levels are increased up to fivefold in the evergreen shrub Phillyrea angustifolia (Munne-Bosch and Penuelas, 2003). The SA content in barley roots is increased approximately twofold by water deficit (Bandurska and Stroiński, 2005). Furthermore, the SA-inducible genes $P R 1$ and $P R 2$ are induced by drought stress (Miura et al., 2013). The induction of SA accumulation may play a role in a protective mechanism during water stress.

However, the effect of SA on drought tolerance remains to be determined because some investigators have reported enhancement of drought tolerance by SA application whereas others have reported a reduction of drought tolerance. Generally, low concentrations of applied SA increase drought tolerance, and high concentrations decrease drought tolerance. As described above, SA induces ROS production in photosynthetic tissues (Borsani et al., 2001). Thus, the application of a high concentration of SA may cause high levels of oxidative stress, leading to decreased abiotic stress tolerance. Both drought tolerance and plant growth are suppressed when a high concentration $(2-3 \mathrm{mM})$ of SA is applied to wheat seedlings, whereas plant growth is enhanced by the application of a low concentration $(0.5 \mathrm{mM})$ of SA (Kang et al., 2012). When wheat seeds were soaked in $100 \mathrm{ppm}$ acetyl SA, the wheat exhibited resistance to drought stress (Hamada, 2001). The application of acetyl SA in the range of $0.1-1 \mathrm{mM}$ also enhanced the drought tolerance of muskmelon seedlings (Korkmaz et al., 2007). The imbibition of tomato and bean seeds in $0.1-0.5 \mathrm{mM}$ SA or acetyl SA increased plant tolerance to heat, chilling, and drought stresses (Senaratna et al., 2000). The treatment of barley with SA decreased the damaging effect of water deficits on the cell membranes in the leaves (Bandurska and Stroiński, 2005). Interestingly, SA treatment increased the ABA content and proline levels in the leaves of barley (Bandurska and Stroiński, 2005). The endogenous SA-accumulating Arabidopsis mutants adr1, myb96-1d, siz1, acd6, and cpr5 exhibit both SA-dependent disease resistance and drought tolerance (Bowling et al., 1997; Rate et al., 1999; Grant et al., 2003; Chini etal., 2004; Lee et al., 2007; Seo et al., 2009; Seo and Park, 2010; Miura et al., 2013). The introduction of the pepper pathogen-induced gene CAPIP2 confers upon Arabidopsis resistance to disease and tolerance to drought (Lee et al., 2006). The pretreatment with $0.5 \mathrm{mM}$ SA alleviates substantial water loss from wheat seedlings, leading to an enhancement of drought tolerance (Kang et al., 2012) by influencing the ascorbate-glutathione cycle (Kang et al., 2013).

Proteomics has revealed 37 protein spots that are up-regulated by pretreatment with SA under drought stress. Several stress defense proteins, such as glutathione $S$-transferases, APX, and 2-cysteine peroxiredoxin, are included (Kang et al., 2012), suggesting that SA pretreatment enhances the antioxidant defense system to protect against the oxidative damage caused by drought stress. Proteins involved in ATP synthesis are also up-regulated by SA and drought, most likely due to an increase in growth and to coping with drought stress. In contrast, 21 protein spots, including Rubisco and related enzymes, are down-regulated by SA but up-regulated by treatment with both SA and drought (Kang et al., 2012). Pretreatment with SA enhances photosynthesis under abiotic stress conditions (Singh and Usha, 2003; Syeed et al., 2011). A comparison of microarray data for SA, drought, and $\mathrm{H}_{2} \mathrm{O}_{2}$ treatments and SA-accumulating (siz1 and cpr5) or SA-deficient (sid2) mutants revealed that 27 genes in two clusters are up-regulated by SA, drought, and the SA-accumulating mutants sizl and cpr5. Among these genes, 9 are highly expressed in guard cells (Miura et al., 2013), including LTI30. The overexpression of LTI29 and LTI30 enhances the accumulation of dehydrins and improves the tolerance to freezing stress (Puhakainen et al., 2004). Because dehydrins play an important role in the tolerance to salt and drought stresses (Brini et al., 2007), LTI29 and LTI30 may be involved in the enhancement of drought tolerance.

\section{SA AND COLD STRESS TOLERANCE}

Temperature is also a major factor of abiotic stresses, and it is a key determinant of agricultural yield and crop productivity. The amount and rate of the uptake of water and nutrients are decreased by cold stresses, leading to cell desiccation and starvation. Extreme forms of cold stresses are called freezing stresses and cause ice formation in cell liquids, leading to dehydration and plant death. Cold temperatures promote the accumulation of endogenous free SA and glucosyl SA in Arabidopsis shoots, wheat, and grape berry (Scott et al., 2004; Wan et al., 2009; Kosova et al., 2012), suggesting that SA is involved in the regulation of cold responses.

The application of $0.5 \mathrm{mM}$ SA improved the cold tolerance of maize, cucumber, and rice (Kang and Saltveit, 2002). Exogenous SA also decreased freezing injury in the leaves of winter wheat grown under low temperature conditions (Taşgín et al., 2003). Chilling injury in freshly harvested green bell pepper (Capsicum 
annuum) was alleviated by methyl SA and methyl jasmonate (JA) vapors (Fung et al., 2004). This reduction of chilling injury in the green bell pepper was correlated with an increase in the expression of the alternative oxidase $(A O X)$ gene induced by methyl SA and methyl JA vapors (Fung et al., 2004). The expression of AOX increased in response to low temperature stresses in rice (Ito et al., 1997), and the capacity of the alternative respiratory pathway and the expression of $A O X$ were enhanced under chilling stress (Feng et al., 2008). These observations suggest that an alternative respiratory pathway is involved in the plant response to cold stresses. Lower concentrations of acetyl SA $(0.1 \mathrm{mM})$ or methyl JA $(3 \mu \mathrm{M})$ significantly improved the seed germination and emergence of sweet pepper (Korkmaz, 2005). Potatoes treated with $0.1 \mathrm{mM}$ SA exhibited freezing tolerance (Mora-Herrera et al., 2005). The application of a $0.5-\mathrm{mM}$ SA solution by spraying the leaves or irrigating the roots of banana seedlings for 1 day improved the chilling tolerance (Kang et al., 2003). When tomato and bean seeds are soaked in aspirin or SA solution $(0.1-0.5 \mathrm{mM})$ before sowing, the cold tolerance of these plants is improved (Senaratna et al., 2000). The hydroponic application of SA or aspirin also increased the chilling tolerance and alleviated the accumulation of both $\mathrm{H}_{2} \mathrm{O}_{2}$ and superoxide radials in the roots and leaves under chilling stress (Wang et al., 2012). SA treatment is effective at alleviating chilling injury, which is one of the most severe postharvest losses of peach fruits. Interestingly, the combination of SA and ultrasound treatment greatly inhibited the chilling injury of peach fruits compared to SA treatment alone (Yang et al., 2012). The application of low concentrations of methyl JA and methyl SA to tomato fruits alleviated the chilling injury and the incidence of decay during low-temperature storage (Ding et al., 2002).

Additionally, high concentrations and the continual application of SA cause severe growth damage and a decrease in the cold tolerance capacity. The Arabidopsis SA over-accumulating mutants, such as acd6, cpr5, and siz1 (Bowling et al., 1997; Rate et al., 1999; Lee etal., 2007), are dwarf-like plants due to the reduction of cell elongation and cell proliferation (Rate et al., 1999; Kirik etal., 2001; Miura et al., 2010). Plants from seeds imbibed in a high concentration of SA $(1 \mathrm{mM})$ did not show any alteration of chilling tolerance, whereas low concentrations of SA $(0.1-0.5 \mathrm{mM})$ promoted tolerance to chilling stress in bean and tomato (Senaratna et al., 2000). Winter and spring wheat to which a hydroponic solution of SA was continually applied were severely damaged by freezing temperatures (Horváth et al., 2007), even though the (not continual) application of SA with a foliar spray enhanced the freezing tolerance of winter wheat (Taşgín et al., 2003). The endogenous accumulation of SA by a mutation may cause effects that are similar to those observed after the continual application of SA. The Arabidopsis SA-accumulating mutant cpr1 exhibited a very high accumulation of SA and a strong growth retardation under chilling stress, whereas the growth of $n a h G$ and eds5, in which the accumulation of SA is very low, was greater than that of wild-type plants under low temperature conditions (Scott et al., 2004). The Arabidopsis cpr1 mutant was damaged by oxidative stress (Scott et al., 2004). It is likely that endogenous SA accumulation triggers production of ROS, which causes cold sensitivity. The other SA-accumulating mutants, acd6 and siz1, were also sensitive to freezing temperatures, whereas the introduction of nah $G$ into acd6 and sizl recovered the sensitivity (Miura and Ohta, 2010). The icel mutant, which was originally isolated as a cold-sensitive mutant (Chinnusamy etal., 2003), exhibited an up-regulation of SA-inducible genes (Miura and Ohta, 2010) and enhanced resistance to bacterial pathogens (Zhu et al., 2011). The overexpression of DEAR1 (DREB and EAR motif protein) enhanced the accumulation of SA and the freezing sensitivity (Tsutsui et al., 2009). OsWRKY13 enhanced the disease resistance and decreased the salt and cold tolerance in rice (Qiu et al., 2008). These data suggest that temporal application of SA may enhance the cold tolerance but that continual application may decrease this tolerance. Furthermore, CAMTA3/AtSR1, which encodes a calmodulin-binding transcription activator, recognizes the $C B F 2 / D R E B 1 C$ promoter to positively regulate the expression of $C B F 2 / D R E B 1 C$ to enhance cold tolerance (Doherty et al., 2009), contributes to the up-regulation of $15 \%$ of the cold-inducible genes (Kim et al., 2013). Furthermore, CAMTA3/AtSR1 binds to the promoter of EDS1 to repress its expression and disease resistance (Du et al., 2009). These results suggest that cold signaling and SA signaling may be interrelated and that the effect of SA on cold tolerance may be tissue-specific and dependent on the organism, concentration, and period of application.

\section{SALINITY AND OSMOTIC STRESS TOLERANCES REGULATED BY SA}

Salinity stress causes not only cellular sodium toxicity, which destroys the ionic homeostasis and ionic distribution, but also osmotic stress. Salinity stress usually copes with water stress imposed by the low external water potential. More than $20 \%$ of irrigated lands are affected by high salt concentrations, and salinity is a common feature of arid and semiarid lands. The endogenous SA level and the activity of the SA biosynthesis enzyme benzoic acid 2-hydroxylase were induced by salinity in rice seedlings (Sawada et al., 2006). The results suggest that SA plays a role in the response to salinity.

The salt-induced decrease in photosynthetic activity and the concentrations of leaf $\mathrm{Na}^{+}, \mathrm{Cl}^{-}$, and $\mathrm{H}_{2} \mathrm{O}_{2}$ were alleviated by the application of SA ( 0.1 or $0.5 \mathrm{mM}$ ) to mung bean (Khan et al., 2010; Nazar et al., 2011). However, high concentrations of SA (1.0 mM) caused growth retardation (Nazar et al., 2011). The exogenous application of SA also improves tolerance to salt stress in several species. The salt tolerance, profitable yield production, and oil content were improved by the application of SA to sunflower plants (Noreen and Ashraf, 2010). Strawberry plants treated with SA exhibited greater growth, as did higher chlorophyll concentrations under salt stress (Karlidag et al., 2009). Tomato plants treated with $0.01 \mathrm{mM}$ SA via root drenching improved the plants' growth and increased the accumulation of photosynthetic pigments, the $\mathrm{K}^{+}$ concentration, and the soluble sugar concentration (Wasti et al., 2012). Pretreatment of tomato with SA in hydroponic culture triggered the accumulation of ABA, leading to an improved acclimation to salt stress (Szepesi et al., 2009). The application of SA improved barley plant growth by promoting protective reactions involving the photosynthetic pigments and maintaining membrane integrity (El-Tayeb, 2005). SA improved wheat plant growth and promoted the accumulation of $\mathrm{ABA}$ and proline (Shakirova 
et al., 2003). The lipid peroxidation and membrane permeability were decreased by SA in maize under salinity stress, leading to the enhancement of plant growth (Gunes et al., 2007). The exogenous application of SA to common bean plants improved plant growth, and the endogenous SA content decreased the growth (Palma et al., 2009). The inhibition of the salt-induced plant growth and photosynthetic capacity of the Medicago sativa-Sinorhizobium meliloti symbiosis were alleviated by pretreatment with 0.1 and $0.5 \mathrm{mM}$ SA (Palma et al., 2013). The nodule biomass was not affected by salinity in SA-pretreated Medicago sativa plants, leading to the maintenance of the nitrogen fixation capacity under salt stress (Palma et al., 2013). The ameliorative effects of SA on salinity stress included a decrease in the $\mathrm{Na}^{+}$content and an increase in the $\mathrm{K}^{+}$concentration in chamomile (Kovacik et al., 2009). The $\mathrm{NaCl}$-induced $\mathrm{K}^{+}$efflux from the roots was prevented by the pretreatment of Arabidopsis with $0.01-0.5 \mathrm{mM}$ SA, resulting in enhanced $\mathrm{K}^{+}$retention and improved shoot growth (Jayakannan et al., 2013). High salinity inhibited the germination of Arabidopsis seeds. Lower concentrations of SA $(<50 \mu \mathrm{M})$ reduced the inhibitory effect of high salinity, while higher concentrations of SA (>100 $\mu \mathrm{M}$ ) enhanced this effect (Lee et al., 2010). Another report demonstrated that necrotic lesions induced by $\mathrm{NaCl}$ treatment were ameliorated in SA-deficient Arabidopsis nahG plants (Borsani et al., 2001), in which the glutathione/oxidized glutathione ratio and the ascorbate/dehydroascorbate ratio were greater during salt stress (Cao et al., 2009).

Drought, salinity, and low temperature stress induce osmotic stress, leading to turgor loss. Several reports demonstrate that the application of SA also affects osmotic stress responses. The addition of SA $(0.05 \mathrm{mM})$ to hydroponic solutions containing media and polyethylene glycol (PEG) alleviated the harmful effects of osmotic stress on wheat seedlings (Marcińska et al., 2013). Exogenous SA application positively impacted the colonization of the endophyte Penicillium resedanum and relieved the adverse effects of osmotic stress by decreasing losses in C. annuum biomass (Khan et al., 2013). The Arabidopsis wrky54wrky70 mutant, which accumulates high levels of endogenous SA, exhibited tolerance to PEG-induced osmotic stress, which was correlated with improved water retention and enhanced stomatal closure (Li et al., 2013).

\section{RELATIONSHIP BETWEEN SA AND ROS IN RESPONSE TO ABIOTIC STRESSES, INCLUDING WATER, SALINITY, AND COLD STRESSES}

The effects of SA on plant tolerance to abiotic stresses appear to be contradictory. The same SA concentration can enhance the tolerance to one type of stress but decrease the resistance to another type of stress (Németh et al., 2002). Generally, a deficiency or very high level of SA decreases plant tolerance to abiotic stresses. In most low-level SA plants, such as Arabidopsis and tobacco, treatment with $0.1-0.5 \mathrm{mM} \mathrm{SA}$ is optimal for eliciting the highest level of stress tolerance (Németh et al., 2002; He et al., 2005; Shi et al., 2006). The basal level of total SA containing free SA (active) and SAG (inactive) in Arabidopsis or tobacco is $0.25-1 \mu \mathrm{g} / \mathrm{g}$ or less than $0.1 \mu \mathrm{g} / \mathrm{g}$ fresh weight, respectively (Yalpani et al., 1991; Malamy et al., 1992; Nawrath and Métraux, 1999; Wildermuth et al., 2001). The free SA level in Arabidopsis is less than $50 \mathrm{ng} / \mathrm{g}$ fresh weight (Kiefer and Slusarenko, 2003). Additionally, rice contains higher levels of endogenous SA (5-30 $\mu \mathrm{g} / \mathrm{g}$ fresh weight; Yang et al., 2004). Pretreatment with SA at this concentration $(0.1-0.5 \mathrm{mM})$ causes low levels of ROS accumulation (Harfouche et al., 2008). As described above, ROS production mediated by SHAM-sensitive guaiacol peroxidases was induced by SA in guard cells (Mori et al., 2001; Khokon et al., 2011). In addition to peroxidases, other SA effectors are involved in the generation of ROS. APX, catalase, and carbonic anhydrase, which are SA effectors and are involved in scavenging ROS, were inhibited by SA (Chen et al., 1993; Conrath et al., 1995; Durner and Klessig, 1995; Slaymaker et al., 2002). The inhibition of these enzymes by SA induces an increase in the ROS levels. Low ROS levels act as secondary signal molecules to enhance the activities of cellular protective enzymes, including APX, catalase, superoxide dismutase (SOD), guaiacol peroxidase (GPX), glutathione reductase (GR), alternative oxidase (AOX), and heat shock protein (HSP; Janda et al., 1999; Kang and Saltveit, 2002; Taşgín et al., 2003; He et al., 2005; Shi et al., 2006). Non-enzymatic antioxidants such as glutathione, ascorbic acid, carotenoids, and tocopherols can contribute to scavenging ROS (Miyake and Asada, 1994; Telfer et al., 1994, 2003; Shimaoka et al., 2003; Kanwischer et al., 2005; Krieger-Liszkay and Trebst, 2006; Ramel et al., 2012).

The application of high concentrations of SA (usually more than $1 \mathrm{mM}$ ) induces high levels of ROS accumulation, leading to a decrease in the capacity to scavenge ROS (Mittler, 2002). The overaccumulation of ROS causes oxidative burst, cell death, and a high level of oxidative stress (Leon et al., 1995; Mateo et al., 2006), leading to a decrease in abiotic stress tolerance. Lesion formation due to the accumulation of $\mathrm{H}_{2} \mathrm{O}_{2}$ in the cat 2 mutant, which is impaired in catalase 2 (Queval et al., 2007), is alleviated by the introduction of sid2, which is defective in ICS1 (Chaouch et al., 2010). This result indicates that the effect of oxidative stress relies on the IC pathway of SA synthesis. SA and ROS, mainly $\mathrm{H}_{2} \mathrm{O}_{2}$, have been proposed to form a self-amplifying feedback loop in response to abiotic and biotic stresses (Vlot et al., 2009). Stress-induced redox regulation is accompanied by the accumulation of ethylene and nitric oxide (NO), and these molecules participate in the SA-ROS self-amplifying loop (Figure 2; Steffens et al., 2013). The reaction of the free radical superoxide with $\mathrm{NO}$ results in the generation of the cytotoxic compound peroxynitrite $\left(\mathrm{ONOO}^{-}\right)$, which induces oxidative burst and cell death (Yoshioka et al., 2011). Under abiotic stresses, treatment with an ethylene precursor increases ROS production, and SA-induced cell death is activated by ethylene signaling (Poor et al., 2013). High concentrations of both $\mathrm{H}_{2} \mathrm{O}_{2}$ and SA were involved in the disruption of normal mitochondrial

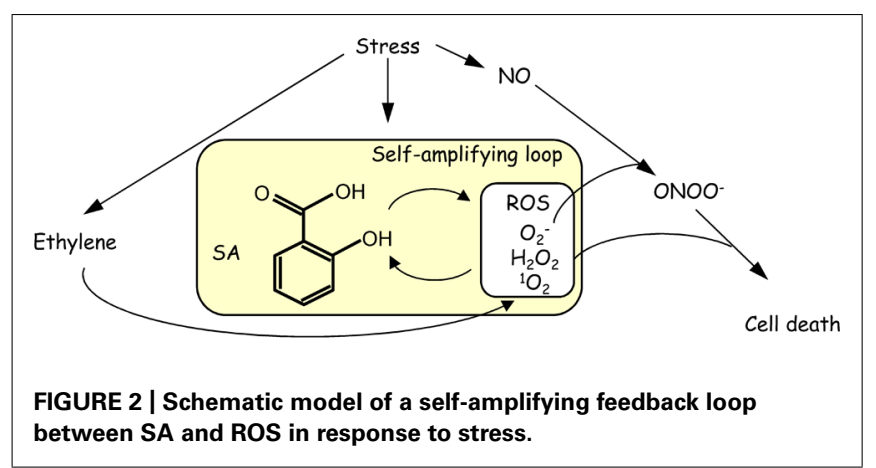




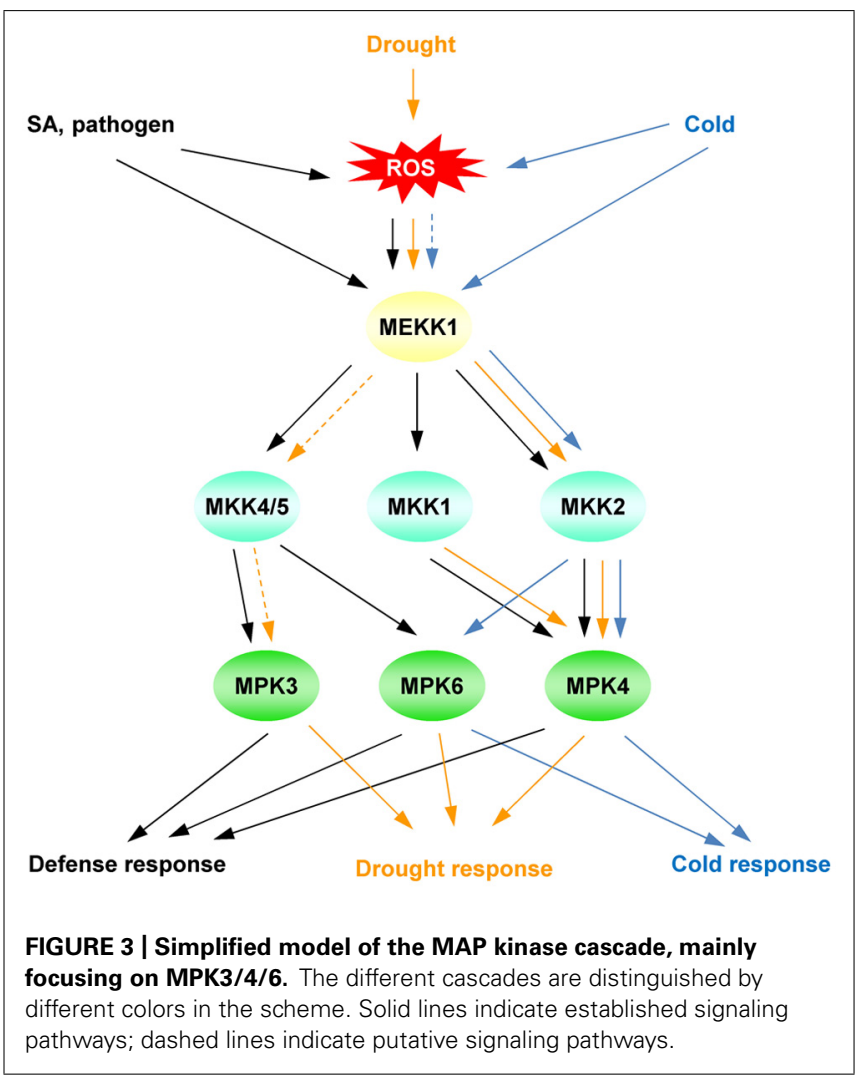

function, leading to decreased electron transport rates and cellular ATP levels (Norman et al., 2004). Intracellular stresses may be recognized by mitochondria, which transduce signals to the nucleus for gene expression alteration.

A MAP kinase (MPK) cascade may be involved in the transmission of the SA/ROS signal to regulate downstream genes (Rodriguez et al., 2010). Several abiotic stresses primarily activate MPK3, MPK4, and MPK6 in Arabidopsis (Figure 3; Ichimura et al., 2000; Moon et al., 2003; Ahlfors et al., 2004; Droillard et al., 2004; Teige et al., 2004; Gudesblat et al., 2007). These MPKs are also activated by SA, PAMPs, and ROS (Figure 3; Petersen et al., 2000; Asai et al., 2002; Droillard et al., 2004). MAPK cascades are conserved signaling modules in eukaryotes. In a general model, MAP kinase kinase kinases (MEKKs) are activated, and phosphorylate MAP kinase kinases (MKKs), which activate MPKs. MPK6 and MPK3, are the Arabidopsis homologs of SA-induced protein kinase (Zhang and Klessig, 1997) and wound-induced protein kinase (Yap et al., 2005), respectively, and are activated by MKK4 and MKK5. The phosphorylation of MPK6 is associated with the application of SA to Arabidopsis roots (Mockaitis and Howell, 2000).

Genetically, the MEKK1-MKK1/2-MPK4 cascade plays a negative role in the regulation of defense responses because the loss of function of either MEKK1 or MPK4 prompts the accumulation of SA (Ichimura et al., 2006; Suarez-Rodriguez et al., 2007). Similarly, ROS activate these MAP kinase cascades. ANP1, an Arabidopsis NPK1-like protein kinase 1, is activated by $\mathrm{H}_{2} \mathrm{O}_{2}$, leading to the phosphorylation of MPK3/MPK6 in Arabidopsis plants
(Kovtun et al., 2000). The MEKK1-MPK4 cascade also plays an essential role in ROS metabolism (Nakagami et al., 2006). $\mathrm{H}_{2} \mathrm{O}_{2}$ accumulates in mekk1 and mpk4 mutants and activates MEKK1 in protoplasts. Because the MEKK1 protein level is also increased by $\mathrm{H}_{2} \mathrm{O}_{2}$ (Nakagami et al., 2006), the MEKK1-MPK4 cascade may be part of a feedback loop that regulates and responds to ROS levels. These MAPK cascades are controlled by both SA and ROS. Because oxidative stress is a common response to biotic and abiotic stresses, ROS homeostasis is a convergence point to evaluate the plant stress status.

\section{CONCLUDING REMARKS}

Salicylic acid plays an important role in the regulation of the abiotic stress responses described above. Application of the appropriate concentration of SA enhances tolerance to abiotic stresses, thereby not only mitigating the damaging effects of abiotic stress tolerance but also enhancing biotic stress tolerance. The important characteristic of SA application is the concentration of applied SA and the method of application, such as foliar spray and hydroponic culture. These methods depend on the plant species; therefore, contradictory results can be reported. Generally, low concentrations or the transient application of SA promotes plant tolerance to abiotic stresses, and high concentrations or the continual application of SA induce inhibitory effects on plant growth and reduce tolerance. It is clear that SA is a very promising compound for the reduction of the abiotic stress sensitivity of numerous plant species.

It remains unclear how SA plays a specific role in abiotic stresses. The accumulation of endogenous SA is induced by several abiotic and biotic stresses. However, how the accumulation of SA is distinguished by each stress is not understood. If the mechanism of how plants distinguish the induction of SA by each stress is understood, this knowledge would contribute to the clarification of the specificity of plant responses to abiotic stresses.

\section{ACKNOWLEDGMENTS}

The laboratories are supported by a grant for Scientific Research on Innovative Areas from the Ministry of Education, Culture, Sports, Science and Technology of the Japanese Government (MEXT) on "Environmental Sensing of Plants: Signal Perception, Processing Cellular Responses" and a Grant in Aid for Challenging Exploratory Research, and Cooperative Research Grant of Gene Research Center, University of Tsukuba.

\section{REFERENCES}

Ackerson, R. C., and Krieg, D. R. (1977). Stomatal and nonstomatal regulation of water use in cotton, corn, and sorghum. Plant Physiol. 60, 850-853. doi: 10.1104/pp.60.6.850

Aharoni, N., Blumenfeld, A., and Richmond, A. E. (1977). Hormonal activity in detached lettuce leaves as affected by leaf water content. Plant Physiol. 59, 11691173. doi: 10.1104/pp.59.6.1169

Ahlfors, R., Macioszek, V., Rudd, J., Brosché, M., Schlichting, R., Scheel, D., et al. (2004). Stress hormone-independent activation and nuclear translocation of mitogen-activated protein kinases in Arabidopsis thaliana during ozone exposure. Plant J. 40, 512-522. doi: 10.1111/j.1365-313X.2004. 02229.x

Allan, A. C., and Fluhr, R. (1997). Two distinct sources of elicited reactive oxygen species in tobacco epidermal cells. Plant Cell 9, 1559-1572. doi: 10.1105/tpc.9.9.1599 
Asai, T., Tena, G., Plotnikova, J., Willmann, M. R., Chiu, W.-L., Gomez-Gomez, L., et al. (2002). MAP kinase signalling cascade in Arabidopsis innate immunity. Nature 415, 977-983. doi: 10.1038/415977a

Bandurska, H., and Stroiński, A. (2005). The effect of salicylic acid on barley response to water deficit. Acta Physiol. Plant. 27, 379-386. doi: 10.1007/s11738005-0015-5

Blatt, M. R., Grabov, A., Brearley, J., Hammond-Kosack, K., and Jones, J. D. G. (1999). $\mathrm{K}^{+}$channels of Cf- 9 transgenic tobacco guard cells as targets for Cladosporium fulvum Avr9 elicitor-dependent signal transduction. Plant J. 19, 453-462. doi: 10.1046/j.1365-313x.1999.00534.x

Borsani, O., Valpuesta, V., and Botella, M. A. (2001). Evidence for a role of salicylic acid in the oxidative damage generated by $\mathrm{NaCl}$ and osmotic stress in Arabidopsis seedlings. Plant Physiol. 126, 1024-1030. doi: 10.1104/pp.126. 3.1024

Bowling, S. A., Clarke, J. D., Liu, Y., Klessig, D. F., and Dong, X. (1997). The cpr5 mutant of Arabidopsis expresses both NPR1-dependent and NPR1-independent resistance. Plant Cell 9, 1573-1584. doi: 10.1105/tpc.9.9.1573

Brini, F., Hanin, M., Lumbreras, V., Amara, I., Khoudi, H., Hassairi, A., et al. (2007). Overexpression of wheat dehydrin DHN-5 enhances tolerance to salt and osmotic stress in Arabidopsis thaliana. Plant Cell Rep. 26, 2017-2026. doi: 10.1007/s00299-007-0412-x

Cao, H., Glazebrook, J., Clarke, J. D., Volko, S., and Dong, X. (1997). The Arabidopsis NPR1 gene that controls systemic acquired resistance encodes a novel protein containing ankyrin repeats. Cell 88, 57-63. doi: 10.1016/S0092-8674(00)81858-9

Cao, Y., Zhang, Z. W., Xue, L. W., Du, J. B., Shang, J., Xu, F., et al. (2009). Lack of salicylic acid in Arabidopsis protects plants against moderate salt stress. $Z$ Naturforsch. C 64, 231-238.

Catinot, J., Buchala, A., Abou-Mansour, E., and Metraux, J. P. (2008). Salicylic acid production in response to biotic and abiotic stress depends on isochorismate in Nicotiana benthamiana. FEBS Lett. 582, 473-478. doi: 10.1016/j.febslet.2007.12.039

Chadha, K. C., and Brown, S. A. (1974). Biosynthesis of phenolic acids in tomato plants infected with Agrobacterium tumefaciens. Can. J. Bot. 52, 2041-2047. doi: $10.1139 / \mathrm{b} 74-262$

Chaouch, S., Queval, G., Vanderauwera, S., Mhamdi, A., Vandorpe, M., LangloisMeurinne, M., et al. (2010). Peroxisomal hydrogen peroxide is coupled to biotic defense responses by ISOCHORISMATE SYNTHASE1 in a daylength-related manner. Plant Physiol. 153, 1692-1705. doi: 10.1104/pp.110.153957

Chen, Z., Silva, H., and Klessig, D. F. (1993). Active oxygen species in the induction of plant systemic acquired resistance by salicylic acid. Science 262, 1883-1886. doi: $10.1126 /$ science. 8266079

Chini, A., Grant, J. J., Seki, M., Shinozaki, K., and Loake, G. J. (2004). Drought tolerance established by enhanced expression of the CC-NBS-LRR gene, ADR1, requires salicylic acid, EDS1 and ABI1. Plant J. 38, 810-822. doi: 10.1111/j.1365313X.2004.02086.x

Chinnusamy, V., Ohta, M., Kanrar, S., Lee, B. H., Hong, X., Agarwal, M., et al (2003). ICE1: a regulator of cold-induced transcriptome and freezing tolerance in Arabidopsis. Genes Dev. 17, 1043-1054. doi: 10.1101/gad.1077503

Cominelli, E., Galbiati, M., Vavasseur, A., Conti, L., Sala, T., Vuylsteke, M., et al. (2005). A guard-cell-specific MYB transcription factor regulates stomatal movements and plant drought tolerance. Curr. Biol. 15, 1196-1200. doi: 10.1016/j.cub.2005.05.048

Conrath, U., Chen, Z., Ricigliano, J. R., and Klessig, D. F. (1995). Two inducers of plant defense responses, 2,6-dichloroisonicotinec acid and salicylic acid, inhibit catalase activity in tobacco. Proc. Natl. Acad. Sci. U.S.A. 92, 7143-7147. doi: 10.1073/pnas.92.16.7143

Delaney, T. P., Friedrich, L., and Ryals, J. A. (1995). Arabidopsis signal transduction mutant defective in chemically and biologically induced disease resistance. Proc. Natl. Acad. Sci. U.S.A. 92, 6602-6606. doi: 10.1073/pnas.92.14.6602

Dempsey, D. A., Vlot, A. C., Wildermuth, M. C., and Klessig, D. F. (2011) Salicylic acid biosynthesis and metabolism. Arabidopsis Book 9, e0156. doi: 10.1199/tab.0156

Desikan, R., Last, K., Harrett-Williams, R., Tagliavia, C., Harter, K., Hooley, R., et al. (2006). Ethylene-induced stomatal closure in Arabidopsis occurs via AtrbohFmediated hydrogen peroxide synthesis. Plant J. 47, 907-916. doi: 10.1111/j.1365313X.2006.02842.x

Dewdney, J., Reuber, T. L., Wildermuth, M. C., Devoto, A., Cui, J., Stutius, L. M., et al. (2000). Three unique mutants of Arabidopsis identify eds loci required for limiting growth of a biotrophic fungal pathogen. Plant J. 24, 205-218. doi: 10.1046/j.1365-313x.2000.00870.x

Ding, C. K., Wang, C. Y., Gross, K. C., and Smith, D. L. (2002). Jasmonate and salicylate induce the expression of pathogenesis-related-protein genes and increase resistance to chilling injury in tomato fruit. Planta 214, 895-901. doi: 10.1007/s00425-001-0698-9

Doherty, C. J., Van Buskirk, H. A., Myers, S. J., and Thomashow, M. F. (2009) Roles for Arabidopsis CAMTA transcription factors in cold-regulated gene expression and freezing tolerance. Plant Cell 21, 972-984. doi: 10.1105/tpc.108. 063958

Dong, F. C., Wang, P. T., and Song, C. P. (2001). The role of hydrogen peroxide in salicylic acid-induced stomatal closure in Vicia faba guard cells. Acta Phytophysiol. Sin. 27, 296-302

Droillard, M.-J., Boudsocq, M., Barbier-Brygoo, H., and Laurière, C. (2004). Involvement of MPK4 in osmotic stress response pathways in cell suspensions and plantlets of Arabidopsis thaliana: activation by hypoosmolarity and negative role in hyperosmolarity tolerance. FEBS Lett. 574, 42-48. doi: 10.1016/j.febslet.2004.08.001

Du, H., and Klessig, D. F. (1997). Identification of a soluble, high-affinity salicylic acid-binding protein in tobacco. Plant Physiol. 113, 1319-1327. doi: 10.1104/pp.113.4.1319

Du, L., Ali, G. S., Simons, K. A., Hou, J., Yang, T., Reddy, A. S., et al. (2009). $\mathrm{Ca}^{2+} /$ calmodulin regulates salicylic-acid-mediated plant immunity. Nature 457, 1154-1158. doi: 10.1038/nature07612

Durner, J., and Klessig, D. F. (1995). Inhibition of ascorbate peroxidase by salicylic acid and 2,6-dichloroisonicotinic acid, two inducers of plant defense responses. Proc. Natl. Acad. Sci. U.S.A. 92, 11312-11316. doi: 10.1073/pnas.92.24.11312

Durrant, W. E., and Dong, X. (2004). Systemic acquired resistance. Annu. Rev. Phytopathol. 42, 185-209. doi: 10.1146/annurev.phyto.42.040803.140421

el-Basyouni, S. Z., Chen, D., Ibrahim, R. K., Neish, A. C., and Towers, G. H. N. (1964). The biosynthesis of hydroxybenzoic acids in higher plants. Phytochemistry 3, 485-492. doi: 10.1016/S0031-9422(00)88025-5

El-Tayeb, M. A. (2005). Response of barley grains to the interactive effect of salinity and salicylic acid. Plant Growth Regul. 45, 215-224. doi: 10.1007/s10725-0054928-1

Ellis, B. E., and Amrhein, N. (1971). The 'NIH-shift' during aromatic ortho-hydroxylation in higher plants. Phytochemistry 10, 3069-3072. doi: 10.1016/S0031-9422(00)97354-0

Feng, H., Li, X., Duan, J., Li, H., and Liang, H. (2008). Chilling tolerance of wheat seedlings is related to an enhanced alternative respiratory pathway. Crop Sci. 48, 2381-2388. doi: 10.2135/cropsci2007.04.0232

Forouhar, F., Yang, Y., Kumar, D., Chen, Y., Fridman, E., Park, S. W., et al. (2005). Structural and biochemical studies identify tobacco SABP2 as a methyl salicylate esterase and implicate it in plant innate immunity. Proc. Natl. Acad. Sci. U.S.A. 102, 1773-1778. doi: 10.1073/pnas.0409227102

Fu, Z. Q., Yan, S., Saleh, A., Wang, W., Ruble, J., Oka, N., et al. (2012). NPR3 and NPR4 are receptors for the immune signal salicylic acid in plants. Nature 486, 228-232. doi: 10.1038/nature11162

Fung, R. W. M., Wang, C. Y., Smith, D. L., Gross, K. C., and Tian, M. (2004). MeSA and MeJA increase steady-state transcript levels of alternative oxidase and resistance against chilling injury in sweet peppers (Capsicum annuum L.). Plant Sci. 166, 711-719. doi: 10.1016/j.plantsci.2003.11.009

Garcion, C., Lohmann, A., Lamodiere, E., Catinot, J., Buchala, A., Doermann, P., et al. (2008). Characterization and biological function of the ISOCHORISMATE SYNTHASE2 gene of Arabidopsis. Plant Physiol. 147, 1279-1287. doi: 10.1104/pp.108.119420

Gehring, C. A., Irving, H. R., Mcconchie, R., and Parish, R. W. (1997). Jasmonates induce intracellular alkalinization and closure of Paphiopedilum guard cells. Ann. Bot. 80, 485-489. doi: 10.1006/anbo.1997.0471

Gehring, C. A., McConchie, R. M., Venis, M. A., and Parish, R. W. (1998) Auxin-binding-protein antibodies and peptides influence stomatal opening and alter cytoplasmic pH. Planta 205, 581-586. doi: 10.1007/s0042500 50359

Grant, J. J., Chini, A., Basu, D., and Loake, G. J. (2003). Targeted activation tagging of the Arabidopsis NBS-LRR gene, ADR1, conveys resistance to virulent pathogens. Mol. Plant Microbe Interact. 16, 669-680. doi: 10.1094/MPMI.2003.16.8.669

Gudesblat, G. E., Iusem, N. D., and Morris, P. C. (2007). Guard cell-specific inhibition of Arabidopsis MPK3 expression causes abnormal stomatal responses 
to abscisic acid and hydrogen peroxide. New Phytol. 173, 713-721. doi: 10.1111/j.1469-8137.2006.01953.x

Gunes, A., Inal, A., Alpaslan, M., Eraslan, F., Bagci, E. G., and Cicek, N. (2007). Salicylic acid induced changes on some physiological parameters symptomatic for oxidative stress and mineral nutrition in maize (Zea mays L.) grown under salinity. J. Plant Physiol. 164, 728-736. doi: 10.1016/j.jplph.2005.12.009

Hamada, A. M. (2001). Salicylic acid versus salinity-drought-induced stress on wheat seedlings. Rostl. Vyr. 47, 444-450.

Hara, M., Furukawa, J., Sato, A., Mizoguchi, T., and Miura, K. (2012). "Abiotic stress and role of salicylic acid in plants," in Abiotic Stress Responses in Plants, eds A. Parvaiza and M. N. V. Prasad (New York, NY: Springer), 235-251.

Harfouche, A. L., Rugini, E., Mencarelli, F., Botondi, R., and Muleo, R. (2008). Salicylic acid induces $\mathrm{H}_{2} \mathrm{O}_{2}$ production and endochitinase gene expression but not ethylene biosynthesis in Castanea sativa in vitro model system. J. Plant Physiol. 165, 734-744. doi: 10.1016/j.jplph.2007.03.010

Haubrick, L. L., Torsethaugen, G., and Assmann, S. M. (2006). Effect of brassinolide, alone and in concert with abscisic acid, on control of stomatal aperture and potassium currents of Vicia faba guard cell protoplasts. Physiol. Plant 128, 134 143. doi: 10.1111/j.1399-3054.2006.00708.x

He, J. H., Wang, P. T., Wang, W. J., and Song, C. P. (2007). Effect of salicylic acid on stomatal movement and $\mathrm{K}^{+}$channel on plasmamembrane of guard cells in Vicia faba L. Acta Agro. Sin. 33, 1479-1787.

He, Y., Liu, Y., Cao, W., Huai, M., Xu, B., and Huang, B. (2005). Effects of salicylic acid on heat tolerance associated with antioxidant metabolism in Kentucky bluegrass. Crop Sci. 45, 988-995. doi: 10.2135/cropsci2003.0678

Hetherington, A. M., and Woodward, F. I. (2003). The role of stomata in sensing and driving environmental change. Nature 424, 901-908. doi: 10.1038/nature01843

Horváth, E., Pál, M., Szalai, G., Páldi, E., and Janda, T. (2007). Exogenous 4hydroxybenzoic acid and salicylic acid modulate the effect of short-term drought and freezing stress on wheat plants. Biol. Plant. 51, 480-487. doi: 10.1007/s10535007-0101-1

Ichimura, K., Casais, C., Peck, S. C., Shinozaki, K., and Shirasu, K. (2006). MEKK1 is required for MPK4 activation and regulates tissue-specific and temperaturedependent cell death in Arabidopsis. J. Biol. Chem. 281, 36969-36976. doi: 10.1074/jbc.M605319200

Ichimura, K., Mizoguchi, T., Yoshida, R., Yuasa, T., and Shinozaki, K. (2000). Various abiotic stresses rapidly activate Arabidopsis MAP kinases ATMPK4 and ATMPK6. Plant J. 24, 655-665. doi: 10.1046/j.1365-313x.2000.00913.x

Irving, H. R., Gehring, C. A., and Parish, R. W. (1992). Changes in cytosolic pH and calcium of guard cells precede stomatal movements. Proc. Natl. Acad. Sci. U.S.A. 89, 1790-1794. doi: 10.1073/pnas.89.5.1790

Ito, Y., Saisho, D., Nakazono, M., Tsutsumi, N., and Hirai, A. (1997). Transcript levels of tandem-arranged alternative oxidase genes in rice are increased by low temperature. Gene 203, 121-129. doi: 10.1016/S0378-1119(97)00502-7

Janda, T., Szalai, G., Tari, I., and Páldi, E. (1999). Hydroponic treatment with salicylic acid decreases the effects of chilling injury in maize (Zea mays L.) plants. Planta 208, 175-180. doi: 10.1007/s004250050547

Jayakannan, M., Bose, J., Babourina, O., Rengel, Z., and Shabala, S. (2013). Salicylic acid improves salinity tolerance in Arabidopsis by restoring membrane potential and preventing salt-induced $\mathrm{K}^{+}$loss via a GORK channel. J. Exp. Bot. 64, 2255 2268. doi: 10.1093/jxb/ert085

Jewer, P. C., and Incoll, L. D. (1980). Promotion of stomatal opening in the grass Anthephora pubescens nees by a range of natural and synthetic cytokinis. Planta 150, 218-221. doi: 10.1007/BF00390829

Kang, G., Li, G., Xu, W., Peng, X., Han, Q., Zhu, Y., et al. (2012). Proteomics reveals the effects of salicylic acid on growth and tolerance to subsequent drought stress in wheat. J. Proteome Res. 11, 6066-6079. doi: 10.1021/pr300728y

Kang, G., Wang, C., Sun, G., and Wang, Z. (2003). Salicylic acid changes activities of $\mathrm{H}_{2} \mathrm{O}_{2}$-metabolizing enzymes and increases the chilling tolerance of banana seedlings. Environ. Exp. Bot. 50, 9-15. doi: 10.1016/S0098-8472(02) 00109-0

Kang, G. Z., Li, G. Z., Liu, G. Q., Xu, W., Peng, X. Q., Wang, C. Y., et al. (2013). Exogenous salicylic acid enhances wheat drought tolerance by influence on the expression of genes related to ascorbate-glutathione cycle. Biol. Plant 57, 718-724. doi: 10.1007/s10535-013-0335-z

Kang, H. M., and Saltveit, M. E. (2002). Chilling tolerance of maize, cucumber and rice seedling leaves and roots are differentially affected by salicylic acid. Physiol. Plant 115, 571-576. doi: 10.1034/j.1399-3054.2002.1150411.x
Kanwischer, M., Porfirova, S., Bergmuller, E., and Dormann, P. (2005). Alterations in tocopherol cyclase activity in transgenic and mutant plants of Arabidopsis affect tocopherol content, tocopherol composition, and oxidative stress. Plant Physiol. 137, 713-723. doi: 10.1104/pp.104045908

Karlidag, H., Yildirim, E., and Turan, M. (2009). Salicylic acid ameliorates the adverse effect of salt stress on strawberry. Sci. Agric. 66, 180-187. doi: 10.1590/S0103-90162009000200006

Khan, A., Waqas, M., Hamayun, M., Al-Harrasi, A., Al-Rawahi, A., and Lee, I.-J. (2013). Co-synergism of endophyte Penicillium resedanum LK6 with salicylic acid helped Capsicum annuum in biomass recovery and osmotic stress mitigation. BMC Microbiol. 13:51. doi: 10.1186/1471-2180-13-51

Khan, N., Syeed, S., Masood, A., Nazar, R., and Iqbal, N. (2010). Application of salicylic acid increases contents of nutrients and antioxidative metabolism in mungbean and alleviates adverse effects of salinity stress. Int. J. Plant Biol. 1, e1. doi: $10.4081 / \mathrm{pb} .2010 . \mathrm{e} 1$

Khokon, A. R., Okuma, E., Hossain, M. A., Munemasa, S., Uraji, M., Nakamura, Y., et al. (2011). Involvement of extracellular oxidative burst in salicylic acidinduced stomatal closure in Arabidopsis. Plant Cell Environ. 34, 434-443. doi: 10.1111/j.1365-3040.2010.02253.x

Kiefer, I. W., and Slusarenko, A. J. (2003). The pattern of systemic acquired resistance induction within the Arabidopsis rosette in relation to the pattern of translocation. Plant Physiol. 132, 840-847. doi: 10.1104/pp.103. 021709

Kim, Y., Park, S., Gilmour, S. J., and Thomashow, M. F. (2013). Roles of CAMTA transcription factors and salicylic acid in configuring the low-temperature transcriptome and freezing tolerance of Arabidopsis. Plant J. 75, 364-376. doi: 10.1111/tpj.12205

Kilian, J., Whitehead, D., Horak, J., Wanke, D., Weinl, S., Batistic, O., et al. (2007). The AtGenExpress global stress expression data set: protocols, evaluation and model data analysis of UV-B light, drought and cold stress responses. Plant J. 50, 347-363. doi: 10.1111/j.1365-313X.2007.03052.x

Kirik, V., Bouyer, D., Schobinger, U., Bechtold, N., Herzog, M., Bonneville, J. M., et al. (2001). CPR5 is involved in cell proliferation and cell death control and encodes a novel transmembrane protein. Curr. Biol. 11, 1891-1895. doi: 10.1016/S0960-9822(01)00590-5

Korkmaz, A. (2005). Inclusion of acetyl salicylic acid and methyl jasmonate into the priming solution improves low-temperature germination and emergence of sweet pepper. HortScience 40, 197-200.

Korkmaz, A., Uzunlu, M., and Demirkiran, A. (2007). Treatment with acetyl salicylic acid protects muskmelon seedlings against drought stress. Acta Physiol. Plant. 29, 503-508. doi: 10.1007/s11738-007-0060-3

Kosova, K., Prasil, I. T., Vitamvas, P., Dobrev, P., Motyka, V., Flokova, K., et al. (2012). Complex phytohormone responses during the cold acclimation of two wheat cultivars differing in cold tolerance, winter Samanta and spring Sandra. J. Plant Physiol. 169, 567-576. doi: 10.1016/j.jplph.2011.12.013.

Kovacik, J., Klejdus, B., Hedbavny, J., and Backor, M. (2009). Salicylic acid alleviates $\mathrm{NaCl}$-induced changes in the metabolism of Matricaria chamomilla plants. Ecotoxicology 18, 544-554. doi: 10.1007/s10646-009-0312-317

Kovtun, Y., Chiu, W. L., Tena, G., and Sheen, J. (2000). Functional analysis of oxidative stress-activated mitogen-activated protein kinase cascade in plants. Proc. Natl. Acad. Sci. U.S.A. 97, 2940-2945. doi: 10.1073/pnas.97.6.2405

Krieger-Liszkay, A., and Trebst, A. (2006). Tocopherol is the scavenger of singlet oxygen produced by the triplet states of chlorophyll in the PSII reaction centre. J. Exp. Bot. 57, 1677-1684. doi: 10.1093/jxb/erl002

Kwak, J. M., Mori, I. C., Pei, Z. M., Leonhardt, N., Torres, M. A., Dangl, J. L., et al. (2003). NADPH oxidase AtrbohD and AtrbohF genes function in ROS-dependent ABA signaling in Arabidopsis. EMBO J. 22, 2623-2633. doi: 10.1093/emboj/cdg277

Lane, B. G., Dunwell, J. M., Ray, J. A., Schmitt, M. R., and Cuming, A. C. (1993). Germin, a protein marker of early plant development, is an oxalate oxidase. J. Biol. Chem. 268, 12239-12242.

Leckie, C. P., Mcainsh, M. R., Allen, G. J., Sanders, D., and Hetherington, A. M. (1998). Abscisic acid-induced stomatal closure mediated by cyclic ADPribose. Proc. Natl. Acad. Sci. U.S.A. 95, 15837-15842. doi: 10.1073/pnas.95.26. 15837

Lee, J., Nam, J., Park, H. C., Na, G., Miura, K., Jin, J. B., et al. (2007). Salicylic acid-mediated innate immunity in Arabidopsis is regulated by SIZ1 SUMO E3 ligase. Plant J. 49, 79-90. doi: 10.1111/j.1365-313X.2006.02947.x 
Lee, S., Choi, H., Suh, S., Doo, I. S., Oh, K. Y., Choi, E. J., et al. (1999). Oligogalacturonic acid and chitosan reduce stomatal aperture by inducing the evolution of reactive oxygen species from guard cells of tomato and Commelina communis. Plant Physiol. 121, 147-152. doi: 10.1104/pp.121.1.147

Lee, S., Kim, S.-G., and Park, C-M. (2010). Salicylic acid promotes seed germination under high salinity by modulating antioxidant activity in Arabidopsis. New Phytol. 188, 626-637. doi: 10.1111/j.1469-8137.2010.03378.x

Lee, S. C., Kim, S. H., An, S. H., Yi, S. Y., and Hwang, B. K. (2006). Identification and functional expression of the pepper pathogen-induced gene, CAPIP2, involved in disease resistance and drought and salt stress tolerance. Plant Mol. Biol. 62, 151.

Leon, J., Lawton, M. A., and Raskin, I. (1995). Hydrogen peroxide stimulates salicylic acid biosynthesis in tobacco. Plant Physiol. 108, 1673-1678. doi $10.1104 /$ pp.108.4.1673

Li, J., Besseau, S., Toronen, P., Sipari, N., Kollist, H., Holm, L., et al. (2013). Defenserelated transcription factors WRKY70 and WRKY54 modulate osmotic stress tolerance by regulating stomatal aperture in Arabidopsis. New Phytol. 200, 457472. doi: $10.1111 /$ nph. 12378

Liang, Y. K., Dubos, C., Dodd, I. C., Holroyd, G. H., Hetherington, A. M., and Campbell, M. M. (2005). AtMYB61, an R2R3-MYB transcription factor controlling stomatal aperture in Arabidopsis thaliana. Curr. Biol. 15, 1201-1206. doi: 10.1016/j.cub.2005.06.041

Liu, F., Jensen, C. R., and Andersen, M. N. (2004). Drought stress effect on carbohydrate concentration in soybean leaves and pods during early reproductive development: its implication in altering pod set. Field Crops Res. 86, 1-13. doi: 10.1016/S0378-4290(03)00165-5

Liu, K., and Luan, S. (1998). Voltage-dependent $\mathrm{K}^{+}$channels as targets of osmosensing in guard cells. Plant Cell 10, 1957-1970. doi: 10.1105/tpc.10.11.1957

Liu, X., Meng, F. X., Zhang, S. Q., and Lou, C. H. (2003). $\mathrm{Ca}^{2+}$ is involved in the signal transduction during stomatal movement induced by salicylic acid in Vicia faba. J. Plant Physiol. Mol. Biol. 1, 59-64.

Lohse, G., and Hedrich, R. (1992). Characterization of the plasma-membrane $\mathrm{H}^{+}$-ATPase from Vicia faba guard cells. Planta 188, 206-214. doi: 10.1007/BF00216815

Malamy, J., Hennig, J., and Klessig, D. F. (1992). Temperature-dependent induction of salicylic acid and its conjugates during the resistance response to tobacco mosaic virus infection. Plant Cell 4, 359-366. doi: 10.1105/tpc.4.3.359

Marcińska, I., Czyczyło-Mysza, I., Skrzypek, E., Grzesiak, M., Janowiak, F., Filek, M., et al. (2013). Alleviation of osmotic stress effects by exogenous application of salicylic or abscisic acid on wheat seedlings. Int. J. Mol. Sci. 14, 13171-13193. doi: 10.3390/ijms140713171

Mateo, A., Funck, D., Muhlenbock, P., Kular, B., Mullineaux, P. M., and Karpinski, S. (2006). Controlled levels of salicylic acid are required for optimal photosynthesis and redox homeostasis. J. Exp. Bot. 57, 1795-1807. doi: 10.1093/jxb/erj196

Melotto, M., Underwood, W., Koczan, J., Nomura, K., and He, S. Y. (2006). Plant stomata function in innate immunity against bacterial invasion. Cell 126, 969980. doi: 10.1016/j.cell.2006.06.054

Mercado-Blanco, J., Van Der Drift, K. M., Olsson, P. E., Thomas-Oates, J. E., Van Loon, L. C., and Bakker, P. A. (2001). Analysis of the pmsCEAB gene cluster involved in biosynthesis of salicylic acid and the siderophore pseudomonine in the biocontrol strain Pseudomonas fluorescens WCS374. J. Bacteriol. 183, 1909-1920. doi: 10.1128/JB.183.6.1909-1920.2001

Mittler, R. (2002). Oxidative stress, antioxidants and stress tolerance. Trends Plant Sci. 7, 405-410. doi: 10.1016/S1360-1385(02)02312-9

Miura, K., Lee, J., Miura, T., and Hasegawa, P. M. (2010). SIZ1 controls cell growth and plant development in Arabidopsis through salicylic acid. Plant Cell Physiol 51, 103-113. doi: 10.1093/pcp/pcp171

Miura, K., and Ohta, M. (2010). SIZ1, a small ubiquitin-related modifier ligase, controls cold signaling through regulation of salicylic acid accumulation. J. Plant Physiol. 167, 555-560. doi: 10.1016/j.jplph.2009.11.003

Miura, K., Okamoto, H., Okuma, E., Shiba, H., Kamada, H., Hasegawa, P. M., etal. (2013). SIZ1 deficiency causes reduced stomatal aperture and enhanced drought tolerance via controlling salicylic acid-induced accumulation of reactive oxygen species in Arabidopsis. Plant J. 49, 79-90. doi: 10.1111/tpj. 12014

Miura, K., Rus, A., Sharkhuu, A., Yokoi, S., Karthikeyan, A. S., Raghothama, K. G., et al. (2005). The Arabidopsis SUMO E3 ligase SIZ1 controls phosphate deficiency responses. Proc. Natl. Acad. Sci. U.S.A. 102, 7760-7765. doi: $10.1073 /$ pnas. 0500778102
Miyake, C., and Asada, K. (1994). Ferredoxin-dependent photoreduction of the monodehydroascorbate radical in spinach thylakoids. Plant Cell Physiol. 35, 539-549.

Mockaitis, K., and Howell, S. H. (2000). Auxin induces mitogenic activated protein kinase (MAPK) activation in roots of Arabidopsis seedlings. Plant J. 24, 785-796. doi: 10.1111/j.1365-313X.2000.00921.x

Moon, H., Lee, B., Choi, G., Shin, D., Prasad, D. T., Lee, O., et al. (2003). NDP kinase 2 interacts with two oxidative stress-activated MAPKs to regulate cellular redox state and enhances multiple stress tolerance in transgenic plants. Proc. Natl. Acad. Sci. U.S.A. 100, 358-363. doi: 10.1073/pnas.252641899

Mora-Herrera, M. E., López-Delgado, H., Castillo-Morales, A., and Foyer, C. H. (2005). Salicylic acid and $\mathrm{H}_{2} \mathrm{O}_{2}$ function by independent pathways in the induction of freezing tolerance in potato. Physiol. Plant 125, 430-440. doi: 10.1111/j.1399-3054.2005.00572.x

Mori, I. C., Pinontoan, R., Kawano, T., and Muto, S. (2001). Involvement of superoxide generation in salicylic acid-induced stomatal closure in Vicia faba. Plant Cell Physiol. 42, 1383-1388. doi: 10.1093/pcp/pce176

Munemasa, S., Oda, K., Watanabe-Sugimoto, M., Nakamura, Y., Shimoishi, Y., and Murata, Y. (2007). The coronatine-insensitive 1 mutation reveals the hormonal signaling interaction between abscisic acid and methyl jasmonate in Arabidopsis guard cells. Specific impairment of ion channel activation and second messenger production. Plant Physiol. 143, 1398-1407. doi: 10.1104/pp.106.091298

Munne-Bosch, S., and Penuelas, J. (2003). Photo- and antioxidative protection, and a role for salicylic acid during drought and recovery in field-grown Phillyrea angustifolia plants. Planta 217, 758-766. doi: 10.1007/s00425-003-1037-0

Nakagami, H., Soukupova, H., Schikora, A., Zarsky, V., and Hirt, H. (2006). A Mitogen-activated protein kinase kinase kinase mediates reactive oxygen species homeostasis in Arabidopsis. J. Biol. Chem. 281, 38697-38704. doi: 10.1074/jbc.M605293200

Nawrath, C., and Métraux, J. P. (1999). Salicylic acid induction-deficient mutants of Arabidopsis express PR-2 and PR-5 and accumulate high levels of camalexin after pathogen inoculation. Plant Cell 11, 1393-1404. doi: 10.1105/tpc.11.8.1393

Nazar, R., Iqbal, N., Syeed, S., and Khan, N. A. (2011). Salicylic acid alleviates decreases in photosynthesis under salt stress by enhancing nitrogen and sulfur assimilation and antioxidant metabolism differentially in two mungbean cultivars. J. Plant Physiol. 168, 807-815. doi: 10.1016/j.jplph.2010. 11.001

Németh, M., Janda, T., Horváth, E., Páldi, E., and Szalai, G. (2002). Exogenous salicylic acid increases polyamine content but may decrease drought tolerance in maize. Plant Sci. 162, 569-574. doi: 10.1016/S0168-9452(01)00593-3

Noreen, S., and Ashraf, M. (2010). Modulation of salt ( $\mathrm{NaCl})$-induced effects on oil composition and fatty acid profile of sunflower (Helianthus annuus L.) by exogenous application of salicylic acid. J. Sci. Food Agric. 90, 2608-2616. doi: $10.1002 /$ jsfa.4129

Norman, C., Howell, K. A., Millar, A. H., Whelan, J. M., and Day, D. A. (2004). Salicylic acid is an uncoupler and inhibitor of mitochondrial electron transport. Plant Physiol. 134, 492-501. doi: 10.1104/pp.103.031039

Ogawa, D., Nakajima, N., Sano, T., Tamaoki, M., Aono, M., Kubo, A., et al. (2005). Salicylic acid accumulation under $\mathrm{O}_{3}$ exposure is regulated by ethylene in tobacco plants. Plant Cell Physiol. 46, 1062-1072. doi: 10.1093/pcp/pci118

Palma, F., Lluch, C., Iribarne, C., García-Garrido, J., and Tejera García, N. (2009). Combined effect of salicylic acid and salinity on some antioxidant activities, oxidative stress and metabolite accumulation in Phaseolus vulgaris. Plant Growth Regul. 58, 307-316. doi: 10.1007/s10725-009-9380-1

Palma, F., López-Gómez, M., Tejera, N. A., and Lluch, C. (2013). Salicylic acid improves the salinity tolerance of Medicago sativa in symbiosis with Sinorhizobium meliloti by preventing nitrogen fixation inhibition. Plant Sci. 208, 75-82. doi: 10.1016/j.plantsci.2013.03.015

Petersen, M., Brodersen, P., Naested, H., Andreasson, E., Lindhart, U., Johansen, B., et al. (2000). Arabidopsis MAP kinase 4 negatively regulates systemic acquired resistance. Cell 103, 1111-1120. doi: 10.1016/S0092-8674(00)00213-0

Poor, P., Kovacs, J., Szopko, D., and Tari, I. (2013). Ethylene signaling in salt stressand salicylic acid-induced programmed cell death in tomato suspension cells. Protoplasma 250, 273-284. doi: 10.1007/s00709-012-0408-4

Puhakainen, T., Hess, M. W., Makela, P., Svensson, J., Heino, P., and Palva, E. T. (2004). Overexpression of multiple dehydrin genes enhances tolerance to freezing stress in Arabidopsis. Plant Mol. Biol. 54, 743-753. doi: 10.1023/B:PLAN.0000040903.66496.a4 
Qiu, D., Xiao, J., Xie, W., Liu, H., Li, X., Xiong, L., et al. (2008). Rice gene network inferred from expression profiling of plants overexpressing OsWRKY13, a positive regulator of disease resistance. Mol. Plant 1, 538-551. doi: 10.1093/mp/ $\operatorname{ssn} 012$

Queval, G., Issakidis-Bourguet, E., Hoeberichts, F. A., Vandorpe, M., Gakière, B., Vanacker, H., et al. (2007). Conditional oxidative stress responses in the Arabidopsis photorespiratory mutant cat2 demonstrate that redox state is a key modulator of daylength-dependent gene expression, and define photoperiod as a crucial factor in the regulation of $\mathrm{H}_{2} \mathrm{O}_{2}$-induced cell death. Plant J. 52, 640-657. doi: 10.1111/j.1365-313X.2007.03263x

Rahman, A. A., Shalaby, A. F., and Monayeri, M. O. (1971). Effect of moisture stress on metabolic products and ions accumulation. Plant Soil 34, 65-90. doi: 10.1007/BF01372762

Rajasekaran, L. R., and Blake, T. J. (1999). New plant growth regulators protect photosynthesis and enhance growth under drought of jack pine seedlings. $J$ Plant Growth Regul. 18, 175-181. doi: 10.1007/PL00007067

Ramel, F., Birtic, S., Cuiné, S., Triantaphylidès, C., Ravanat, J.-L., and Havaux, M. (2012). Chemical quenching of singlet oxygen by carotenoids in plants. Plant Physiol. 158, 1267-1278. doi: 10.1104/pp.111.182394

Raskin, I. (1992). Role of salicylic acid in plants. Annu. Rev. Plant Physiol. Plant Mol. Biol. 43, 439-463. doi: 10.1146/annurev.pp.43.060192.002255

Rate, D. N., Cuenca, J. V., Bowman, G. R., Guttman, D. S., and Greenberg, J. T. (1999). The gain-of-function Arabidopsis acd6 mutant reveals novel regulation and function of the salicylic acid signaling pathway in controlling cell death, defenses, and cell growth. Plant Cell 11, 1695-1708. doi: 10.1105/tpc.11. 9.1695

Rivas-San Vicente, M., and Plasencia, J. (2011). Salicylic acid beyond defence: its role in plant growth and development. J. Exp. Bot. 62, 3321-3338. doi: 10.1093/jxb/err031

Rodriguez, M. C., Petersen, M., and Mundy, J. (2010). Mitogen-activated protein kinase signaling in plants. Annu. Rev. Plant Biol. 61, 621-649. doi: 10.1146/annurev-arplant-042809-112252

Saito, N., Munemasa, S., Nakamura, Y., Shimoishi, Y., Mori, I. C., and Murata, Y. (2008). Roles of RCN1, regulatory A subunit of protein phosphatase 2A, in methy jasmonate signaling and signal crosstalk between methyl jasmonate and abscisic acid. Plant Cell Physiol. 49, 1396-1401. doi: 10.1093/pcp/pcn 106

Sanchez-Casas, P., and Klessig, D. F. (1994). A salicylic acid-binding activity and a salicylic acid-inhibitable catalase activity are present in a variety of plant species. Plant Physiol. 106, 1675-1679. doi: 10.1104/pp.106.4.1675

Sawada, H., Shim, I-S., and Usui, K. (2006). Induction of benzoic acid 2-hydroxylase and salicylic acid biosynthesis: modulation by salt stress in rice seedlings. Plant Sci. 171, 263-270. doi: 10.1016/j.plantsci.2006.03.020

Schwartz, A., Ilan, N., Schwarz, M., Scheaffer, J., Assmann, S. M., and Schroeder, J. I. (1995). Anion-channel blockers inhibit S-type anion channels and abscisic acid responses in guard cells. Plant Physiol. 109, 651-658. doi: 10.1104/pp.109.2.651

Scott, I. M., Clarke, S. M., Wood, J. E., and Mur, L. A. (2004). Salicylate accumulation inhibits growth at chilling temperature in Arabidopsis. Plant Physiol. 135, 1040 1049. doi: 10.1104/pp.104.041293

Senaratna, T., Touchell, D., Bunn, E., and Dixon, K. (2000). Acetyl salicylic acid (aspirin) and salicylic acid induce multiple stress tolerance in bean and tomato plants. Plant Growth Regul. 30, 157-161. doi: 10.1023/A:1006386800974

Seo, P. J., and Park, C. M. (2010). MYB96-mediated abscisic acid signals induce pathogen resistance response by promoting salicylic acid biosynthesis in Arabidopsis. New Phytol. 186, 471-483. doi: 10.1111/j.1469-8137.2010.03183.x

Seo, P. J., Xiang, F., Qiao, M., Park, J. Y., Lee, Y. N., Kim, S. G., et al. (2009). The MYB96 transcription factor mediates abscisic acid signaling during drought stress response in Arabidopsis. Plant Physiol. 151, 275-289. doi: 10.1104/pp.109.144220

Serino, L., Reimmann, C., Baur, H., Beyeler, M., Visca, P., and Haas, D. (1995). Structural genes for salicylate biosynthesis from chorismate in Pseudomonas aeruginosa. Mol. Gen. Genet. 249, 217-228. doi: 10.1007/BF00290369

Shakirova, F. M., Sakhabutdinova, A. R., Bezrukova, M. V., Fatkhutdinova, R. A., and Fatkhutdinova, D. R. (2003). Changes in the hormonal status of wheat seedlings induced by salicylic acid and salinity. Plant Sci. 164, 317-322. doi: 10.1016/S01689452(02)00415-6

Shi, Q., Bao, Z., Zhu, Z., Ying, Q., and Qian, Q. (2006). Effects of different treatments of salicylic acid on heat tolerance, chlorophyll fluorescence, and antioxidant enzyme activity in seedlings of Cucumis sativa L. Plant Growth Regul. 48, 127-135. doi: 10.1007/s10725-005-5482-6
Shimaoka, T., Miyake, C., and Yokota, A. (2003). Mechanism of the reaction catalyzed by dehydroascorbate reductase from spinach chloroplasts. Eur. J. Biochem. 270, 921-928. doi: 10.1046/j.1432-1033.2003.03452.x

Singh, B., and Usha, K. (2003). Salicylic acid induced physiological and biochemical changes in wheat seedlings under water stress. Plant Growth Regul. 39, 137-141. doi: 10.1023/A:1022556103536

Slaymaker, D. H., Navarre, D. A., Clark, D., Del Pozo, O., Martin, G. B., and Klessig, D. F. (2002). The tobacco salicylic acid-binding protein 3 (SABP3) is the chloroplast carbonic anhydrase, which exhibits antioxidant activity and plays a role in the hypersensitive defense response. Proc. Natl. Acad. Sci. U.S.A. 99, 11640-11645. doi: 10.1073/pnas.182427699

Steffens, B., Steffen-Heins, A., and Sauter, M. (2013). Reactive oxygen species mediate growth and death in submerged plants. Front. Plant Sci. 4:179. doi: 10.3389/fpls.2013.00179

Suarez-Rodriguez, M. C., Adams-Phillips, L., Liu, Y., Wang, H., Su, S. H., Jester, P. J., et al. (2007). MEKK1 is required for flg22-induced MPK4 activation in Arabidopsis plants. Plant Physiol. 143, 661-669. doi: 10.1104/pp.106.091389

Suhita, D., Raghavendra, A. S., Kwak, J. M., and Vavasseur, A. (2004). Cytoplasmic alkalization precedes reactive oxygen species production during methyl jasmonate- and abscisic acid-induced stomatal closure. Plant Physiol. 134, 1536-1545. doi: 10.1104/pp.103.032250

Syeed, S., Anjum, N., Nazar, R., Iqbal, N., Masood, A., and Khan, N. (2011). Salicylic acid-mediated changes in photosynthesis, nutrients content and antioxidant metabolism in two mustard (Brassica juncea L.) cultivars differing in salt tolerance. Acta Physiol. Plant. 33, 877-886. doi: 10.1007/s11738-010-0614-7

Szepesi, Á., Csiszár, J., Gémes, K., Horváth, E., Horváth, F., Simon, M. L., et al. (2009). Salicylic acid improves acclimation to salt stress by stimulating abscisic aldehyde oxidase activity and abscisic acid accumulation, and increases $\mathrm{Na}^{+}$content in leaves without toxicity symptoms in Solanum lycopersicum L. J. Plant Physiol. 166, 914-925. doi: 10.1016/j.jplph.2008.11.012

Tanaka, Y., Sano, T., Tamaoki, M., Nakajima, N., Kondo, N., and Hasezawa, S. (2006). Cytokinin and auxin inhibit abscisic acid-induced stomatal closure by enhancing ethylene production in Arabidopsis. J. Exp. Bot. 57, 2259-2266. doi: 10.1093/jxb/erj193

Tanguilig, V. C., Yambao, E. B., O’Toole, J. C., and Datta, S. K. (1987). Water stress effects on leaf elongation, leaf water potential, transpiration, and nutrient uptake of rice, maize, and soybean. Plant Soil 103, 155-168. doi: 10.1007/BF023 70385

Tardieu, F., and Davies, W. J. (1992). Stomatal response to abscisic acid is a function of current plant water status. Plant Physiol. 98, 540-545. doi: 10.1104/pp.98.2.540

Taşgín, E., Atící, Ö., and Nalbantoğlu, B. (2003). Effects of salicylic acid and cold on freezing tolerance in winter wheat leaves. Plant Growth Regul. 41, 231-236. doi: 10.1023/B:GROW.0000007504.41476.c2

Teige, M., Scheikl, E., Eulgem, T., Dóczi, R., Ichimura, K., Shinozaki, K., et al. (2004). The MKK2 pathway mediates cold and salt stress signaling in Arabidopsis. Mol. Cell 15, 141-152. doi: 10.1016/j.molcel.2004.06.023

Telfer, A., Dhami, S., Bishop, S. M., Phillips, D., and Barber, J. (1994). $\beta$-Carotene quenches singlet oxygen formed by isolated photosystem II reaction centers. Biochemistry 33, 14469-14474. doi: 10.1021/bi00252a013

Telfer, A., Frolov, D., Barber, J., Robert, B., and Pascal, A. (2003). Oxidation of the two $\beta$-carotene molecules in the photosystem II reaction center. Biochemistry 42 , 1008-1015. doi: 10.1021/bi026206p

Tsutsui, T., Kato, W., Asada, Y., Sako, K., Sato, T., Sonoda, Y., et al. (2009). DEAR1, a transcriptional repressor of DREB protein that mediates plant defense and freezing stress responses in Arabidopsis. J. Plant Res. 122, 633-643. doi: 10.1007/s10265-009-0252-6

Uppalapati, S. R., Ishiga, Y., Wangdi, T., Kunkel, B. N., Anand, A., Mysore, K. S., et al. (2007). The phytotoxin coronatine contributes to pathogen fitness and is required for suppression of salicylic acid accumulation in tomato inoculated with Pseudomonas syringae pv. tomato DC3000. Mol. Plant Microbe Interact. 20, 955-965. doi: 10.1094/MPMI-20-8-0955

Vlot, A. C., Dempsey, D. M. A., and Klessig, D. F. (2009). Salicylic acid, a multifaceted hormone to combat disease. Annu. Rev. Phytopathol. 47, 177-206. doi: 10.1146/annurev.phyto.050908.135202

Wan, D., Li, R., Zou, B., Zhang, X., Cong, J., Wang, R., et al. (2012). Calmodulin-binding protein CBP60g is a positive regulator of both disease resistance and drought tolerance in Arabidopsis. Plant Cell Rep. 31, 1269-1281. doi: $10.1007 /$ s00299-012-1247-7 
Wan, S. B., Tian, L., Tian, R. R., Pan, Q. H., Zhan, J. C., Wen, P. F., et al. (2009). Involvement of phospholipase D in the low temperature acclimationinduced thermotolerance in grape berry. Plant Physiol. Biochem. 47, 504-510. doi: 10.1016/j.plaphy.2008.12.010

Wang, D., Amornsiripanitch, N., and Dong, X. (2006). A genomic approach to identify regulatory nodes in the transcriptional network of systemic acquired resistance in plants. PLoS Pathog. 2:e123. doi: 10.1371/journal.ppat 0020123

Wang, Y., Hu, J., Qin, G., Cui, H., and Wang, Q. (2012). Salicylic acid analogues with biological activity may induce chilling tolerance of maize (Zea mays) seeds. Botany 90, 845-855. doi: 10.1139/b2012-055

Wasti, S., Mimouni, H., Smiti, S., Zid, E., and Ben Ahmed, H. (2012). Enhanced salt tolerance of tomatoes by exogenous salicylic acid applied through rooting medium. OMICS 16, 200-207. doi: 10.1089/omi.2011.0071

Weng, J.-K., and Chapple, C. (2010). The origin and evolution of lignin biosynthesis. New Phytol. 187, 273-285. doi: 10.1111/j.1469-8137.2010.03327.x

Wildermuth, M. C., Dewdney, J., Wu, G., and Ausubel, F. M. (2001). Isochorismate synthase is required to synthesize salicylic acid for plant defence. Nature 414, 562-565. doi: 10.1038/35107108

Xiong, L., Wang, R.-G., Mao, G., and Koczan, J. M. (2006). Identification of drought tolerance determinants by genetic analysis of root response to drought stress and abscisic acid. Plant Physiol. 142, 1065-1074. doi: 10.1104/pp.106.084632

Yalpani, N., Leon, J., Lawton, M. A., and Raskin, I. (1993). Pathway of salicylic acid biosynthesis in healthy and virus-inoculated tobacco. Plant Physiol. 103, 315-321. doi: 10.1104/pp.103.2.315

Yalpani, N., Silverman, P., Wilson, T. M. A., Kleier, D. A., and Raskin, I. (1991). Salicylic acid is a systemic signal and an inducer of pathogenesis-related proteins in virus-infected tabacco. Plant Cell 3, 809-818. doi: 10.1105/tpc. 3.8.809

Yang, Y., Qi, M., and Mei, C. (2004). Endogenous salicylic acid protects rice plants from oxidative damage caused by aging as well as biotic and abiotic stress. Plant J. 40, 909-919. doi: 10.1111/j.1365-313X.2004.02267.x
Yang, Z., Cao, S., Zheng, Y., and Jiang, Y. (2012). Combined salicyclic acid and ultrasound treatments for reducing the chilling injury on peach fruit. J. Agric. Food Chem. 60, 1209-1212. doi: 10.1021/jf2041164

Yap, Y.-K., Kodama, Y., Waller, F., Chung, K. M., Ueda, H., Nakamura, K., et al. (2005). Activation of a novel transcription factor through phosphorylation by WIPK, a wound-induced mitogen-activated protein kinase in tobacco plants. Plant Physiol. 139, 127-137. doi: 10.1104/pp.105.065656

Yoshioka, H., Mase, K., Yoshioka, M., Kobayashi, M., and Asai, S. (2011). Regulatory mechanisms of nitric oxide and reactive oxygen species generation and their role in plant immunity. Nitric Oxide 25, 216-221. doi: 10.1016/j.niox.2010.12.008

Zhang, S., and Klessig, D. F. (1997). Salicylic acid activates a 48-kD MAP kinase in tobacco. Plant Cell 9, 809-824. doi: 10.1105/tpc.9.5.809

Zhu, Y., Yang, H., Mang, H. G., and Hua, J. (2011). Induction of BAP1 by a moderate decrease in temperature is mediated by ICE1 in Arabidopsis. Plant Physiol. 155, 580-588. doi: 10.1104/pp.110.169466

Conflict of Interest Statement: The authors declare that the research was conducted in the absence of any commercial or financial relationships that could be construed as a potential conflict of interest.

Received: 30 September 2013; accepted: 04 January 2014; published online: 23 January 2014.

Citation: Miura K and Tada Y (2014) Regulation of water, salinity, and cold stress responses by salicylic acid. Front. Plant Sci. 5:4. doi: 10.3389/fpls.2014.00004

This article was submitted to Plant Physiology, a section of the journal Frontiers in Plant Science.

Copyright (C) 2014 Miura and Tada. This is an open-access article distributed under the terms of the Creative Commons Attribution License (CC BY). The use, distribution or reproduction in other forums is permitted, provided the original author(s) or licensor are credited and that the original publication in this journal is cited, in accordance with accepted academic practice. No use, distribution or reproduction is permitted which does not comply with these terms. 